\title{
Fertilisation Methods for Commercial Yield in Three Garlic Cultivars (Allium sativum L.)
}

\author{
Métodos de fertilización para rendimiento comercial en tres cultivares de ajo (Allium sativum L.)
}

\author{
Condor, J.( $\left.{ }^{1}\right)$; Olivera, J.( $\left.{ }^{2}\right)^{*}$; Pinedo, R.( $\left(^{3}\right)$ \\ *Corresponding author: agols4407@gmail.com
}

\begin{abstract}
Garlic (Allium sativum L.) is an important crop for domestic consumption in Peru. However, there is insufficient information available on crop management, particularly on fertiliser application to local cultivars. In order to evaluate the response of three garlic cultivars to three fertilisation methods, an experiment was conducted at the Donoso Experimental Station in Huaral district, a province of Lima. Three garlic cultivars were used as experimental materials: 'Cincomesino', 'Arequipeño 14' and 'Margosino'. Three methods of fertilisation were applied as treatments: broadcast application before furrowing (M1), fertilisation in a superficial groove or false furrow (M2), and fertilisation in the lateral furrows, or band application (M3). The experiments were installed in three parcels for each cultivar, with a randomised complete block design for each parcel and four replications. In general, localised fertilisation methods showed the best performance for the broadcast method. Regarding total yield, fertilisation at the sides of the furrow (M3) for 'Cincomesino' reached 13.08 $\mathrm{t} / \mathrm{ha}$. The highest yield for the 'Arequipeño 14' cultivar (12.25 t/ha) was achieved using fertilisation with a surface groove or false furrow (M2). For the 'Margosino' cultivar, fertilisation on the sides of the furrow was ideal, and the yield was $10.95 \mathrm{t} / \mathrm{ha}$.
\end{abstract}

Keywords: broadcast application, crop yield, false furrow, 'Margosino', nitrogen

\section{Resumen}

El ajo (Allium sativum L.), es un cultivo de importancia para el consumo interno en el Perú. No existe suficiente información disponible sobre el manejo de cultivo, principalmente la fertilización aplicada a los cultivares de uso local. Con el objetivo de evaluar la respuesta del rendimiento comercial de ajo con tres métodos de fertilización, se realizó un experimento en la Estación Experimental Donoso (INIA), ubicada en la provincia de Huaral, región Lima. Como material experimental se emplearon tres cultivares de ajo: 'Cincomesino', 'Arequipeño 14' y 'Margosino' y tres métodos de fertilización: fertilización al voleo antes del surcado (M1), fertilización en surco superficial o falso surco (M2) y fertilización en los laterales del surco o aplicación en banda (M3). Los tratamientos fueron instalados en tres parcelas, una para cada cultivar, bajo un diseño de bloques completos al azar, con cuatro repeticiones. Los resultados mostraron que los métodos de fertilización localizados destacan sobre el método de fertilización al voleo. En relación con el rendimiento total, para el cultivar 'Cincomesino' con el método M3 alcanzó el mejor rendimiento de 13.08 t/ha, seguido del cultivar 'Arequipeño 14', que alcanzó el mayor rendimiento de 12.25 t/ha con M2 y el cultivar 'Margosino' el mayor rendimiento resultó $10.95 \mathrm{t} /$ ha con el tratamiento $\mathrm{M} 3$.

Palabras clave: falso surco, 'Margosino', nitrógeno, rendimiento de cultivo, voleo

\section{Introduction}

Garlic is native to central and southern Asia, from where it spread to the Mediterranean and then to the rest of the world. By around 3000 B.C.E., it was being consumed in India and Egypt (García, 1990). By the end of the 15th century, the Spaniards had introduced it to the Americas (Campelo, Arboleya, Maeso, Paullier \& Giménez, 2016).
Garlic is one of the oldest herbaceous crops (Salomon, 2002).

In Peru, the most widespread garlic cultivars are susceptible to diseases caused by viruses and other pathogens as well as to shortages of quality seed (Nicho \& Cóndor, 2012). Their production is intended for both internal consumption and export as fresh and processed

\footnotetext{
${ }^{1}$ Instituto Nacional de Innovación Agraria (INIA) Estación Experimental Agraria (EEA) Donoso-Huaral. Lima, Perú.

${ }^{2}$ Instituto Nacional de Innovación Agraria (INIA) Estación Experimental Agraria (EEA) Donoso-Huaral, Consultor del Programa de Hortalizas. Lima, Perú.

${ }^{3}$ Universidad Nacional Agraria La Molina (UNALM). Facultad de Agronomía. Docente del Departamento de Fitotecnia. Lima, Perú.
} 
products. In the second quarter of 2017, the area of this crop sown nationwide was 7,600 ha. In the fourth quarter of 2017 , the national yield was $10.8 \mathrm{t} / \mathrm{ha}$. In the Arequipa region, the average yield was $12.3 \mathrm{t} / \mathrm{ha}$ (Sifuentes, Albújar, \& Cajas, 2017; Sifuentes, Albújar, \& Cajas, 2018). Small and medium farms are the primary producers of this crop and most of the national production is destined for the domestic market.

The use of pathogen-free seed allows an increase in the yield of this crop, in some cases exceeding 50\% (Olivera, 2009; Salomon, 2002). The wide gap between the current low yields and the potential yield reveals a series of factors that limit garlic production. Some of these limiting factors are environmental, while others are related to agronomic or cultural practices (Usman, Fagam, Dayi, \& Isah, 2016).

Timely availability of nutrients is an important factor affecting the quantity and quality of garlic crops (Burba, 2003). Proper management of the nutrition of the different garlic cultivars through the timely application of fertilisers is part of the production process which, in combination with other factors, promotes an increase in the yield and quality of crops. In addition, given the increasing price of fertilisers and the environmental costs associated with their excessive use, it is necessary to increase the efficiency of pesticide use (Harold \& Reetz, 2016; Lipinski \& Gaviola, 2006; Mirzaei, Liaghati, \& Damghani, 2007).

The production of horticultural plants requires multiple applications of fertilisers (Ugás, Siura, Delgado, Casas \& Toledo, 2000). Fertilisers that are added to the soil undergo transformations that can modify their availability. Their application methods are directly related to the plant's use of nutrients and the changes these nutrients undergo in the soil. To the extent possible, the application methods used should be economical, accurate and effective (California Fertiliser Association, 1995; Harold \& Reetz, 2016). A fertilisation plan must take into account the variability of environmental and management factors such as irrigation and tillage in order to distribute nitrogen with flexibility, according to the specific conditions of each campaign. A reduction in yield can be avoided by improving the efficiency of nitrogen fertilisation, incidentally mitigating the negative environmental impacts resulting from excess application (Harold \& Reetz, 2016; Quemada, Delgado, Mateos, \& Villalobos, 2017).

Fertiliser (organic or mineral) application methods are essential components of good agricultural practices. The amount and regulation of absorption depend on several factors, such as crop variety, planting date, crop rotation, soil conditions and weather. In efficient agricultural practices, the farmer selects the quantity and opportunity over time, so that plants use the nutrients as efficiently as possible (Asociación Internacional de la Industria de los Fertilizantes [AIIF], 2002).

Recent soil analyses have shown that most soils are deficient in nitrogen (about 100\%) and phosphorous (about 90\%); therefore, proper management of these two elements is critical for good crop production. The proper management of fertilisers should focus on the maximum use of the applied $\mathrm{P}$ and $\mathrm{K}$. For this purpose, alternatives to pre-sowing application over the entire surface, such as localised applications or application in bands (Delgado, Quemada, Villalobos \& Mateos, 2017), must be taken into account. Similarly, the dose of fertilisers should be based on the results of soil analysis, taking as reference a fertiliser dose of 220-100-200 NPK. It is also recommended to perform the first fertilisation $15 \mathrm{~d}$ after planting, with $1 / 3$ of the nitrogen and all phosphorus and potassium, followed by a second nitrogen fertilisation at $30 \mathrm{~d}$ and a third at $60 \mathrm{~d}$ after the initial application (Nicho \& Cóndor, 2012).

There are various methods of application, such as spreading fertiliser uniformly over the entire surface of the land, or broadcasting and modified broadcasting, which is similar, except that fertiliser is applied only on the bed or in thin bands along the bed (Sierra, Simonne, \& Treadwell, 2007). Another system involves localised placement at the base of the plant. In this case, the fertiliser must be located under the teeth or next to them in order to avoid failures in sprouting (García, 1990). Nitrogen is usually the only nutrient with insufficient availability for the cultivation of garlic, and the use of this element in three applications during cultivation is common practice. According to Burba (2003), the first application should be $30 \%$ of the dose, the second $35 \%$ and the third 35\%, while Aguado, Portela, and Lipinski (2014) recommends 25\%-35\%-40\%, starting 50 or $60 \mathrm{~d}$ after the beginning of leaf emergence.

Broadcast fertilisation (that is, application to the surface of a crop field) is mainly used in dense crops not sown in rows or sown in dense rows (small grains) or in meadows. It is also used when fertilisers need to be incorporated into the soil after application (phosphate fertilisers) or to prevent losses from the evaporation of nitrogen (urea, diammonium phosphate). Incorporation by tillage or plowing is also recommended to increase fertility of the entire plow layer. If the fertiliser is spread by surface broadcasting by hand or with fertiliser distribution equipment, the spreading should be as uniform as possible (AIIF, 2002). In Canada, on clay soils, fertiliser can be broadcast and incorporated prior to planting white garlic to bring soil fertility to $80 \mathrm{~kg} \mathrm{ha}^{-1} \mathrm{~N}$ and $33 \mathrm{~kg} \mathrm{ha}^{-1} \mathrm{P}$ (Bandara, Krieger, Slinkard, \& Tanino, 2000).

When fertiliser application is localised (placed only in selected places in the field), it is concentrated in specific parts of the soil during planting, either in bands, in a strip below the soil surface, or next to and under the seed. This process can be carried out by hand or by means of special sowing equipment and/or equipment for fertiliser application (seed sowing and fertiliser) (AIIF, 2002). In the furrow irrigation system, the most appropriate form of nitrogen fertiliser application is burying it next to the plant line. When adequate machinery is not available, the fertiliser can be placed in the furrow immediately 
after irrigation so that it dissolves and is incorporated (Lipinski, 2015). To reduce fertiliser runoff, nitrogen applications should be split: the first application should be by broadcasting and the second and third application in bands (Nicho \& Cóndor, 2012).

The growth of the garlic plant is slow during the first $100 \mathrm{~d}$; therefore, there is low absorption of nutrients. During that time, the plant partially uses reserve substances in the cloves. This absorption becomes more intense from $100 \mathrm{~d}$ on, extending to the end of the crop development (Campillo \& Toro, 2002). After sowing, both the number of leaves and plant height increase. The onset of bulb formation is characterised by an increase in the ratio of bulb diameter to neck diameter. In this phase, the number of teeth per plant increases rapidly, leaf growth rate decreases and finally, the increase in plant height stops (Brewster \& Rabinowitch, 2002).

Starting with the hypothesis that there are differences in fertiliser application methods that affect the yield of local garlic cultivars, the objective of the present study was to determine the most appropriate method of fertilisation for local garlic cultivars.

\section{Materials and Methods}

The experiment was conducted between July 2017 and January 2018. The plots were located in the Experimental Agricultural Station Donoso-Huaral, $5.6 \mathrm{~km}$ from the city of Huaral, in the region of Lima at a south latitude $11^{\circ} 14^{\prime}$ and 180 masl. The experiment was arranged in a random complete block design and three treatments were installed in each plot corresponding to each cultivar, in four distributed random blocks. Four furrows were installed in each experimental unit. The average temperature of the Huaral Valley (data obtained from the Weather Station of the EEA Donoso-Huaral, corresponding to the year 2017) during the months of crop growth was $17.3{ }^{\circ} \mathrm{C}$ in July and $21.6^{\circ} \mathrm{C}$ in December, while the average relative humidity reached $58.5 \%$ in July. The three experimental plots were located in a sandy strip, according to the analysis of soils with low levels of salts (electrical conductivity: $0.52 \mathrm{mS} /$ $\mathrm{cm})$, moderately alkaline $\mathrm{pH}(7.71)$ and low organic matter content ( $0.7 \%)$, typical of coastal soils (Valladolid, 2001); also high in phosphorus (43 ppm) and potassium (234 ppm), low in calcium carbonate $(10.56 \%)$ and medium cation exchange capacity (CEC) with 10.86 .

The cultivars under study were 'Cincomesino' (C1), 'Arequipeño 14' (C2) and 'Margosino' (C3). The genetic material was provided by the National Vegetable Research Programme of the INIA and the treatments for each cultivar included three methods of fertilisation: Method 1 (M1), broadcast application before furrowing; Method 2 (M2), fertilisation in a surface groove or false furrow; and Method 3 (M3), lateral furrow or band fertilisation. Figure 1 shows the bulbs and cloves of cultivars 'Cincomesino',
'Arequipeño 14' and 'Margosino'.

According to Loayza, Nicho, Cahuas, and Cosme (2005), the early garlic cultivars are those in which the beginning of gradual foliar drying from the basal part to the apical part of the plant is carried out from the fourth
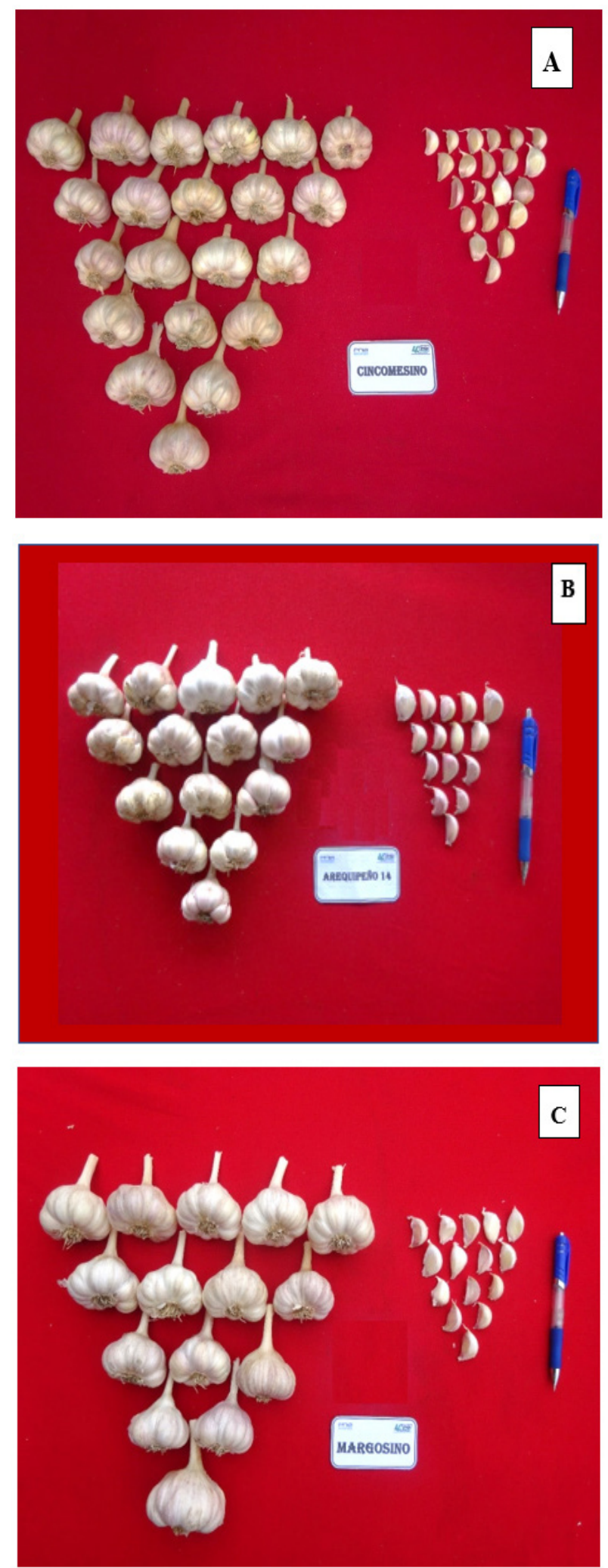

Figure 1. Bulbs and cloves of three garlic cultivars, first calibre: (A) 'Cincomesino', (B) 'Arequipeño 14' and (C) 'Margosino'. 
month to the fifth month, 15 days. This group includes the cultivar 'Cincomesino', which is widespread in Peru, with a vegetative period of 5.0 to 5.5 months (early) and 'Arequipeño 14'; both belong to the Napurí garlic group. The 'Margosino' cultivar belongs to the late cultivar group, for which the beginning of gradual foliar drying from the basal to the apical part occurs from the fifth to the sixth month (Loayza et al., 2005). Based on the results of the soil analysis, we used ammonium sulfate, diammonium phosphate and potassium sulfate at a fertilisation level of 250-80-100 NPK, taking into account the recommendations proposed by the Vegetable Programme of the National Agrarian University (Ugás et al., 2000) of 200-80-100 NPK. However, fertilisation levels differed among experiments.

The experimental data were statistically analysed for each plot corresponding to a different cultivar by analysis of variance using the statistical software SAS at $P<0.05$, and the means were compared using the Duncan test.

Manual sowing was carried out at $10 \mathrm{~cm}$ between plants in double rows with a $60 \mathrm{~cm}$ groove, as recommended by Ugás et al. (2000). With regard to insect pests, the presence of 'thrips' was evaluated, and foliar diseases such as botrytis caused by Botrytis porri and rust caused by Puccinia allii were also evaluated. Control was performed for both pathogens using insecticides and fungicides.

Surface irrigation was carried out weekly based on the physical characteristics of the soil using gravity and the slope of the land. The bulbs were harvested when 70\% of the foliage was dry (145 d after planting), and there was a shortening of the vegetative period due to weather conditions during the experiment.

Vegetative parameters were determined for the three cultivars. Plant height was collected by measuring from the soil surface to the top of the longest leaf of 10 randomly selected plants using a ruler at physiological maturity of the crop, and the mean values in cm were computed for further analysis. To determine the neck thickness of the bulbs using a caliper, 10 random plants were evaluated at the neck level of the plant. Number of leaves per plant was recorded by counting the number of leaves of 10 randomly selected plants per plot at physiological maturity, and the mean value was recorded. Regarding yield parameters, three variables were evaluated. For bulb weight, 10 random bulbs were evaluated and the average bulb weight was determined. Average bulb size was recorded by measuring the diameter at the middle (equatorial diameter) of 10 randomly selected bulbs in each plot using a caliper, and from this parameter, the shape of the bulb was determined. With regard to the polar diameter of bulbs, 10 randomly selected bulbs were evaluated with the help of a caliperan evaluation that helped us determine the bulb shape.

Bulbs were sorted by calibre in accordance with the classifications used in the internal market, such as the wholesale market of Lima, although there is also an export classification mentioned in Loayza et al. (2005) and Nicho and Cóndor (2012).

Among the harvested bulbs, first-calibre bulbs with 6 to $8 \mathrm{~cm}$ equatorial bulb diameter were classified then weighed to determine the bulb weight. The variable yield of second-calibre bulbs included those whose equatorial diameter was in the range of 4 to $6 \mathrm{~cm}$, and the third-calibre yield included those with an equatorial diameter of 2 to 4 $\mathrm{cm}$. To define the total yield/ha, all commercial bulbs were weighed to calculate the yield in $\mathrm{t} / \mathrm{ha}$.

\section{Results}

The experiment was conducted with slightly increased mean temperatures compared to previous campaigns; this climatic variation showed some minor changes in the vegetative period of culture and in the process of clove differentiation, in both cases shortening the process. Likewise, conditions were favourable for the presence of pests and diseases, which had an impact on crop production cost (Nicho \& Cóndor, 2012).

Table 1 shows no statistical difference in plant heights of the early garlic cultivar 'Cincomesino'. M1 showed the best results but did not significantly differ from the other treatments. For neck thickness, no statistical difference between treatments was found, although M1 had the best results. The same occurred with the number of leaves, with a slight increase in M1.

Table 1. Effect of fertilisation methods on vegetative garlic growth in cv. 'Cincomesino'

\begin{tabular}{llll}
\hline Treatments & $\begin{array}{c}\text { Plant height } \\
(\mathrm{cm})\end{array}$ & $\begin{array}{c}\text { Neck thickness } \\
(\mathrm{mm})\end{array}$ & $\begin{array}{c}\text { Leaf } \\
\text { number }\end{array}$ \\
\hline M1 & $(1) 72.1$ & $(3) 9.12$ & $(1) 11.9$ \\
M2 & $(3) 72.0$ & $(1) 8.72$ & $(2) 11.8$ \\
M3 & $(2) 70.3$ & $(2) 8.47$ & $(3) 11.7$ \\
\hline CV\% & 2.12 & 5.71 & 1.65 \\
\hline
\end{tabular}

For bulb polar diameter, there was a statistical difference between treatments. M1 had the highest value, followed by similar means of M3 and M2 (Figure 2). For equatorial bulb diameter, there was no statistically significant difference between treatments, since all treatments resulted in the same mean diameter (Figure 2).

For the yield variable (first calibre) of cv. 'Cincomesino' (Table 2), there was no significant statistical difference between treatments, while M3 had the highest value. For second-calibre yield, there was no significant difference between treatments; M2 had the highest value, similar to that of M1. In the third-calibre yield, there was no significant difference between treatments, and M3 had the highest value. For total yield, the treatments showed no significant statistical difference, while M3 had the highest value (Table 2). 


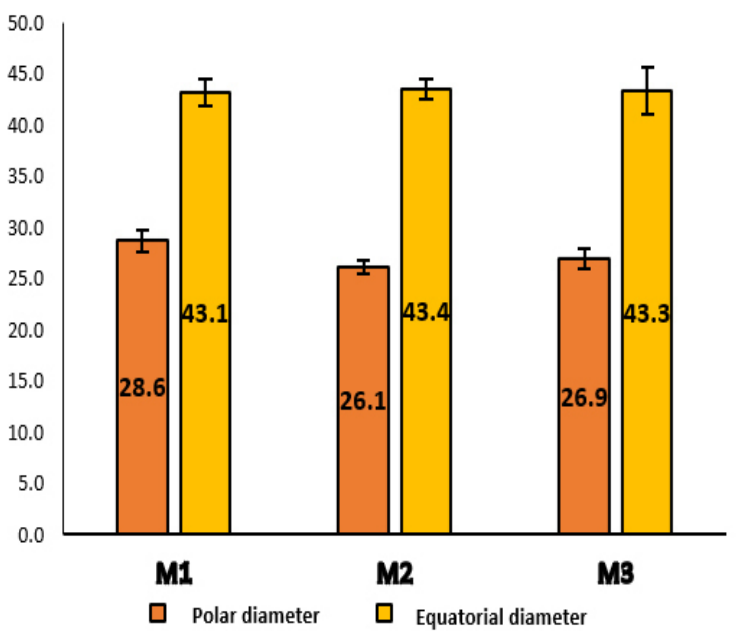

Figure 2. Effects of different methods of fertilisation on garlic bulb size $(\mathrm{mm})$ in cv. 'Cincomesino'. All the values are means \pm SE $(n=10)$.

In cv. 'Arequipeño 14' (Table 2), the first-calibre yield showed no significant differences, while in the secondcalibre yield, M2 was higher than M1 and M3. For the third-calibre yield, M2 showed the highest value. For total yield, M2 displayed the highest value.

For cv. 'Margosino' (Table 2), the first-calibre yield showed no significant difference between treatments, but in the M2 yield, it was superior and similar to that of 'Arequipeño 14'; however, it only reached $4.0 \mathrm{t} / \mathrm{ha}$ in M2. For the second-calibre yield, there were no significant differences either, and in terms of yield in t/ha, M1 and M2 were at $4.67 \mathrm{t} / \mathrm{ha}$, followed by M3 at $4.02 \mathrm{t} / \mathrm{ha}$. For the third-calibre yield, there were no significant differences between M1 and M2, but they were comparable to that of M3. For total yield at the winter planting (July), there were no significant differences, but M3 stood out at $11.0 \mathrm{t} / \mathrm{ha}$, followed by M1 and M2 at $10.9 \mathrm{t} / \mathrm{ha}$.

Plant height (Table 3) showed no significant difference between treatments in cv. 'Arequipeño 14'. M1 reached a greater height than M2 and M3, which were 69.1 and $68.4 \mathrm{~cm}$, respectively. For the neck thickness variable, M1 was $10.0 \mathrm{~mm}$, followed by M2 (in a superficial groove or false furrow), with M3 (fertilisation in the lateral furrows or band application) in third place. For leaf number, no significant difference was found between treatments; the results were similar for M1 and M2, with the same number of leaves and both values slightly greater than those of the M3 treatment.

The Duncan test for polar diameter showed a statistical difference. M3 treatment had the highest value (Figure 3), but the values were similar in the other treatments. For equatorial diameter, M3 had the highest value, showing a greater difference compared to M1 and M2.

Table 3. Effect of fertilisation methods on the garlic vegetative growth of cv. 'Arequipeño-14'

\begin{tabular}{llll}
\hline Treatments & $\begin{array}{c}\text { Plant height } \\
(\mathbf{c m})\end{array}$ & $\begin{array}{c}\text { Neck thickness } \\
(\mathbf{m m})\end{array}$ & $\begin{array}{c}\text { Leaf } \\
\text { number }\end{array}$ \\
\hline M1 & $(3) 69.2$ & $(3) 10.0$ & $(1) 12$ \\
M2 & $(2) 69.1$ & $(1) 9.90$ & $(2) 12$ \\
M3 & $(1) 68.4$ & $(2) 9.70$ & $(3) 12$ \\
\hline CV \% & 2.81 & 8.34 & 3.13 \\
\hline
\end{tabular}

Table 2. Effects of different methods of fertilisation on the yield ( $t / h a)$ of three garlic cultivars: 'Cincomesino', 'Arequipeño 14' and 'Margosino'

\begin{tabular}{cccccc}
\hline Cultivar & T & Yield 1 $^{\text {st }}$ & Yield 2 $^{\text {nd }}$ & Yield 3 $^{\text {rd }}$ & Total yield \\
\hline 'Cincomesino' & M1 & $4.67 \pm 1.19 \mathbf{a}$ & $5.17 \pm 0.33 \mathbf{a}$ & $2.42 \pm 1.11 \mathbf{a}$ & $12.25 \pm 0.31 \mathbf{a}$ \\
& M2 & $5.00 \pm 1.89 \mathbf{a}$ & $5.17 \pm 1.02 \mathbf{a}$ & $2.17 \pm 0.82 \mathbf{a}$ & $12.33 \pm 0.60 \mathbf{a}$ \\
& M3 & $5.33 \pm 1.51 \mathbf{a}$ & $5.08 \pm 1.23 \mathbf{a}$ & $2.67 \pm 1.07 \mathbf{a}$ & $13.08 \pm 0.31 \mathbf{a}$ \\
\hline C.V. \% & & 25.13 & 11.18 & 17.35 & 3.98 \\
\hline 'Arequipeño 14' & M1 & $4.83 \pm 1.35 \mathbf{a}$ & $4.58 \pm 1.20 \mathbf{a}$ & $2.75 \pm 0.67 \mathbf{a}$ & $11.83 \pm 0.57 \mathbf{a}$ \\
& M2 & $5.17 \pm 1.72 \mathbf{a}$ & $5.00 \pm 1.25 \mathbf{a}$ & $2.83 \pm 0.57 \mathbf{a}$ & $12.25 \pm 1.40 \mathbf{a}$ \\
& M3 & $4.83 \pm 0.63 \mathbf{a}$ & $4.58 \pm 0.56 \mathbf{a}$ & $2.17 \pm 0,63 \mathbf{a}$ & $11.58 \pm 1.98 \mathbf{a}$ \\
\hline C.V. \% & & 25.42 & 17.25 & 19.59 & 14.74 \\
\hline 'Margosino' & M1 & $3.92 \pm 1.93 \mathbf{a}$ & $4.67 \pm 1.41 \mathbf{a}$ & $2.33 \pm 1.13 \mathbf{~ b}$ & $10.92 \pm 1.34 \mathbf{a}$ \\
& M2 & $4.00 \pm 0.75 \mathbf{a}$ & $4.67 \pm 1.40 \mathbf{a}$ & $2.21 \pm 1.01 \mathbf{~ b}$ & $10.88 \pm 1.48 \mathbf{a}$ \\
& M3 & $3.58 \pm 1.49 \mathbf{a}$ & $4.02 \pm 0.02 \mathbf{a}$ & $3.38 \pm 0.68 \mathbf{a}$ & $10.96 \pm 1.48 \mathbf{a}$ \\
\hline C.V. \% & & $\mathbf{3 1 . 8}$ & $\mathbf{2 2 . 8}$ & $\mathbf{2 3 . 3}$ & $\mathbf{1 5 . 5 2}$ \\
\hline
\end{tabular}

$\mathrm{T}$ (Treatment)

1 Values expressed by mean $\pm \mathrm{SE}(\mathrm{n}=10)$

2 Different letters indicate statistically significant differences according to Duncan's test $(\mathrm{P} \leq 0.05)$. 


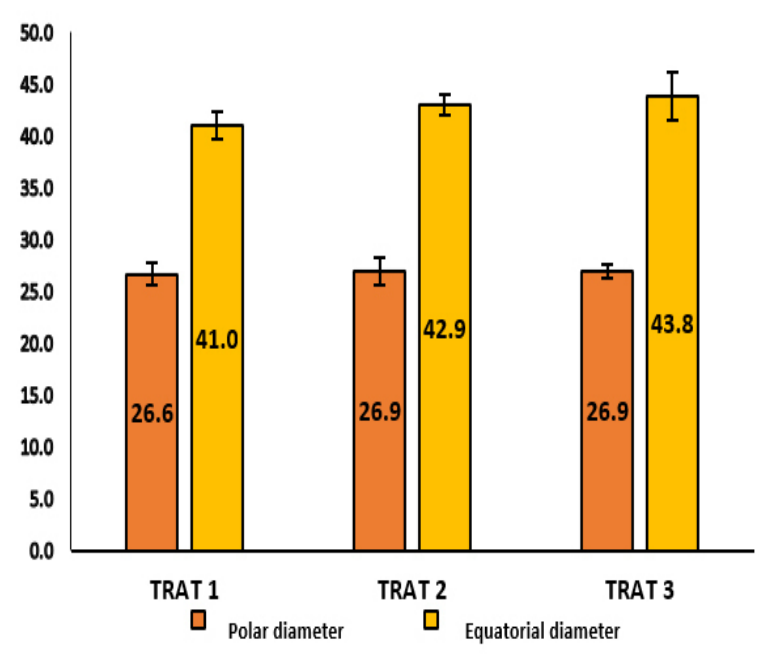

Figure 3. Effect of fertilisation method on garlic bulb size (mm) in cv. 'Arequipeño-14'. All the values are means \pm SE $(n=10)$.

Table 4 Effect of fertilisation methods on the garlic vegetative growth in cv 'Margosino'

\begin{tabular}{llll}
\hline Treatments & $\begin{array}{l}\text { Plant height } \\
\text { (cm) }\end{array}$ & $\begin{array}{l}\text { Neck } \\
\text { thickness } \\
\text { (mm) }\end{array}$ & $\begin{array}{l}\text { Leaf } \\
\text { number }\end{array}$ \\
\hline M1 & $(1) 68,0$ & $(1) 8,88$ & $(3) 12,0$ \\
M2 & $(2) 67,6$ & $(3) 8,50$ & $(1) 12,0$ \\
M3 & $(3) 66,8$ & $(2) 7,85$ & $(2) 11,8$ \\
\hline CV \% & 3,41 & 16,79 & 325 \\
\hline
\end{tabular}

For plant height in cv. 'Margosino' (Table 4), M1 had the highest value compared to the other cultivars under study. For neck thickness, M1 also had the highest value compared to the other treatments; treatments M1 and M3 had the same number of leaves.

M3 had the largest bulb polar diameter, followed by M2 and M3 (Figure 4). For bulb equatorial diameter, a similar relationship was found: M3 in first place, followed closely by M1, then M2.

Figure 5 shows the three cultivars and three methods of fertilisation. The percentages of garlic bulbs of first $(6-8 \mathrm{~cm})$ calibre reached on average $30 \%$ of the total production; however, for the case of 'Cincomesino' and 'Arequipeño-14', M3 (lateral groove fertilisation) had the highest result, and in the case of 'Margosino', M2 (false groove fertilisation) was highest. Among the secondcalibre garlic yield, $40 \%$ of the total production belonged to this group.

According to Table 1, results similar to those of the plant height experiment were recorded by Loayza et al. (2005): $72.6 \mathrm{~cm}$ in the autumn planting season and 75.5 $\mathrm{cm}$ in the winter planting season for cv. 'Cincomesino'. However, reports from other latitudes, in experiments with local cultivars and different levels of nitrogen fertilisation,

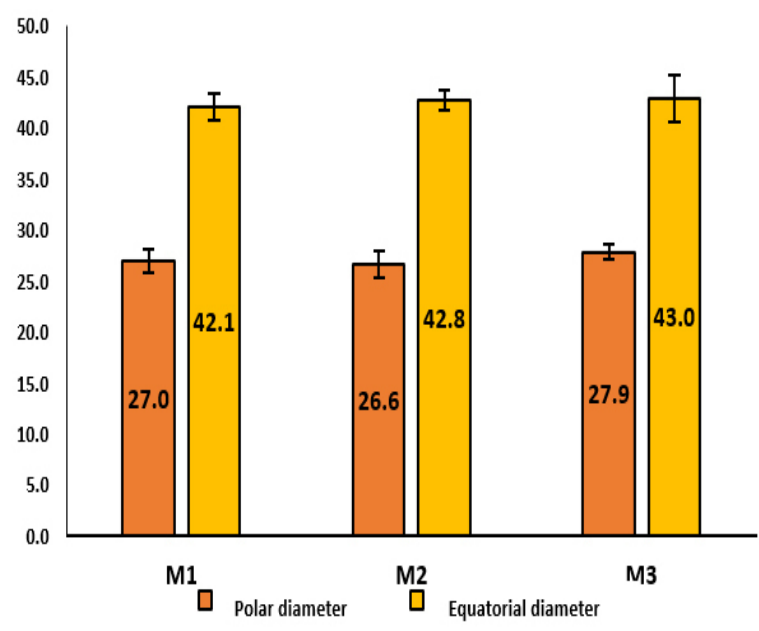

Figure 4. Effect of fertilisation method on garlic bulb size (mm) in cv. 'Margosino'. All values are means \pm SE $(n=10)$.

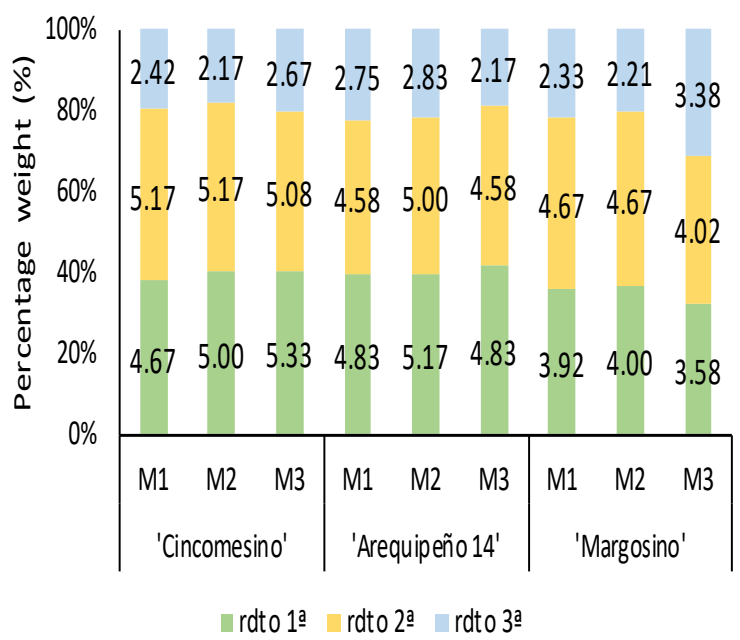

Figure 5. Percentage distribution of bulb weights: first, second and third calibre of three garlic cultivars for different fertilisation methods

recorded a plant height maximum of $56.0 \mathrm{~cm}$ (Naruka \& Dhaka, 2001). For neck thickness, similar results were obtained by Loayza et al. (2005) at $0.87 \mathrm{~cm}$ and $1.19 \mathrm{~cm}$ in the autumn and winter planting season, respectively. For leaf number, the results obtained were in the range reported by Loayza et al. (2005) for this cultivar.

With regard to the plant height of $\mathrm{cv}$. 'Arequipeño 14', M1 reached $69.2 \mathrm{~cm}$, compared to M2 and M3, which reached 69.1 and $68.4 \mathrm{~cm}$, respectively-values that approximate the results of Loayza et al. (2005) of $70.9 \mathrm{~cm}$ in an autumn planting of the same cultivar. For the neck thickness variable, M1 was $10.0 \mathrm{~mm}$, the same as the results of Loayza et al. (2005) for an autumn planting (9.9 $\mathrm{mm})$. For leaf number, no significant difference was found between treatments, with a mean of 12.1 leaves. Loayza et al. (2005) reported a lower number of leaves in the autumn planting and a similar number of leaves in a winter planting. 
Regarding cv. 'Margosino', plant height values reached $68.0 \mathrm{~cm}$ compared to 75.6 in Loayza et al. (2005) for a winter planting. In M1 for neck thickness, $8.88 \mathrm{~mm}$ was the highest value; Loayza et al. (2005) found a larger neck diameter in both the autumn $(11.9 \mathrm{~mm})$ and winter plantings $(13.1 \mathrm{~mm})$. This difference was possibly caused by the weather conditions during the study, which were not favourable for greater thickening of the neck; these can be correlated with the lower plant height obtained. All three treatments showed similar results for number of leaves, with means of 12.0. Loayza et al. (2005) found 12.7 leaves in autumn and 11.6 leaves in winter. Although the plants had a similar number of leaves in terms of neck diameter and plant height, they showed greater plant development.

Total yield in cv. 'Cincomesino' reached $10.4 \mathrm{t} / \mathrm{ha}$ in the winter planting in Loayza et al. (2005), and in the May planting, it reached $14 \mathrm{t} / \mathrm{ha}$ compared to the $13.1 \mathrm{t} /$ ha obtained in the M3 treatment in the present study. In cv. 'Arequipeño', the total yield obtained in M2 was $12.25 \mathrm{t} / \mathrm{ha}$. Loayza et al. (2005) mentions total yields of $9.3 \mathrm{t} / \mathrm{ha}$ for the June planting and $13.3 \mathrm{t} / \mathrm{ha}$ for the May planting. A similar yield was obtained for white garlic in Mexico, where Pérez, García, Ramírez, and Barrera (2003) obtained 12.2 t/ha in cv. 'Cristal'. For cv. 'Margosino', Loayza et al. (2005) found a similar yield of $10.9 \mathrm{t} / \mathrm{ha}$ for the June planting (winter) and 12.0 t/ha for the May planting (autumn), corroborating that the high yields are proportional to the length of the growth period (between sprouting and bulbification), as pointed out by Burba (2003).

Plant height of cv. 'Arequipeño 14' in treatment M1 reached a high of $69.2 \mathrm{~cm}-$ a value that approximates the results of Loayza et al. (2005) in the autumn planting of $70.9 \mathrm{~cm}$. For the neck thickness variable, the M1 result was superior, with the $10.0 \mathrm{~mm}$ result similar to that of $9.9 \mathrm{~mm}$ obtained in the autumn planting by Loayza et al. (2005). For leaf number, no significant difference was found between treatments, with an average of 12.0 leaves. Loayza et al. (2005) reported 11.4 in autumn plantings and 12.7 in winter.

Plant height in cv. 'Margosino' (Table 4) reached a maximum of $68.0 \mathrm{~cm}$ in M1 -less than those recorded by Loayza et al. (2005) of $75.6 \mathrm{~cm}$ in the autumn and $75.7 \mathrm{~cm}$ in the winter planting. For neck thickness, $8.88 \mathrm{~mm}$ was the highest value; Loayza et al. (2005) obtained a larger neck diameter in autumn plantings $(11.9 \mathrm{~mm})$ and in winter plantings $(13.1 \mathrm{~mm})$. This difference was possibly caused by the weather conditions during the study, which were not favourable for thickening of the neck and could be correlated with the lower plant height obtained. Regarding the number of leaves, Loayza et al. (2005) found 12.7 leaves in autumn and 11.6 leaves in winter. Although they had a similar number of leaves, in terms of neck diameter and plant height, the plants showed greater development.

\section{Conclusions}

The vegetative development variables were higher for the broadcast fertilisation method, while the yield and bulb quality variables showed better results for lateral fertilisation in cultivars 'Cincomesino' and 'Margosino'. Thus, this method of fertilisation might be the most suitable depending on the crop yield, owing to the response of the plant to the location of the fertiliser and improved absorption and translocation of nutrients by the plant.

The highest yield for 'Arequipeño-14' was obtained by applying the superficial groove or false furrow fertilisation method, which allowed better uptake owing to its proximity to the roots

\section{Acknowledgements}

The authors wish to thank INIA and the Experimental Agricultural Station Donoso-Huaral for the technological and logistical support received, as well as the technical staff and field personnel of the National Vegetable Programme, who made this study possible.

\section{References}

Aguado, G., Portela, J. \& Lipinski, V. (2014). Fertilizaciòn del cultivo de ajo en la Provincia de Mendoza. Estación Experimental Agropecuaria Mendoza, Argentina: INTA.

Asociación Internacional de la Industria de los Fertilizantes [AIIF] (2002). Los fertilizantes y su uso. (4ta ed.). Paris, Francia: FAO.

Bandara, M. S., Krieger, K., Slinkard, A. E. \& Tanino, K.K. (2000). Pre-plant chilling requirements for cloving of spring-planted garlic. Canadian Journal of Plant Science, 80(2), 379-384. https://doi.org/10.4141/ P99-074

Burba, J. (2003). Producción de ajo. Mendoza, Argentina: INTA.

Brewster, J. L., \& Rabinowitch, H. D. (1990). Garlic agronomy. In J.L. Brewster, \& H.D. Rabinowitch (Eds.), Onion and Allied Crops. Volume III Biochemistry, Food Science, and Minor Crops (pp. 147-158). Florida, EE.UU.: CRC Press.

California Fertilizer Association. (1995). Manual de Fertilizantes para Horticultura. México, D.F.: Limusa.

Campelo, E., Arboleya, J., Maeso, D., Paullier, J., \& Giménez, G. (2016). Producción integrada de ajo. Montevideo, Uruguay: Instituto Nacional de Investigación Agraria (INIA). 
Campillo R., \& Toro, C. (2002). Manejo de la fertilización. En J. Peralta \& M. González (Eds.). Cultivo del ajo (Allium sativum L.) para la zona sur de Chile (pp. 30-51). Temuco, Chile. INIA.

Delgado, A., Quemada, M., Villalobos, F. J., \& Mateos, L. (2017). La fertilización con fósforo, potasio y otros nutrientes. In F. Villalobos, \& E. Fereres (Eds.), Fitotecnia Principios de agronomía para una agricultura sostenible (pp. 425-446). Madrid, España: Mundi-Prensa.

García-Alonso, C.(1990). Elajo Cultivoy aprovechamiento. Madrid, España: Mundi-Prensa.

Harold, F., \& Reetz, Jr. (2016). Fertilizers and their Efficient Use. (First edition). Paris, Francia: International Fertilizer Industry Association (IFA).

Lipinski, V. (2015). Manejo del riego y la fertilización en cultivos de ajo. Mendoza, Argentina: Instituto Nacional Tecnológico Agropecuario (INTA). Retrieved from https://www.argentina.gob.ar/inta

Lipinski, V., \& Gaviola, S. (2006). Evaluación del rendimiento y calidad de cultivares de ajo colorado fertirrigados con nitrógeno. Revista de la Facultad de Ciencias Agrarias, UNCuyo, 38(2), 37-48.

Loayza V. J., Nicho S. P., Cahuas B. J., \& Cosme, C. R. (2005). Descripción agronómica de cultivares de ajo (Allium sativum L. ssp. vulgare) bajo condiciones del valle de Huaral. Boletín técnico $\mathrm{N}^{\mathrm{o}}$ 01-05. Lima, Perú: INIA.

Mirzaei, R., Liaghati, H., \& Damghani, A. (2007). Evaluating yield quality and quantity of garlic as affected by different farming systems and garlic clones. Pakistan Journal of Biological Sciences, 10(13), 2219-2224.

Naruka, I., \& Dhaka, R. (2001). Effect of row spacing and nitrogen fertilization on growth, yield and composition of bulb in garlic (Allium sativum L.) cultivars. Journal of spices and Aromatic Crops, 10(2), 111-117.

Nicho, S. P., \& Cóndor C. J. (2012). Tecnología de producción de ajo. Lima, Perú: INIA. Retrieved from http://repositorio.inia.gob.pe/handle/inia/754

Olivera, S. J. (2009). Técnica de producción de semilla genética y básica de ajo (Allium sativum L.) libre de virus. Serie folleto $N^{\circ}$ 6-09. Lima, Perú: INIA.

Pérez, L., García, P., Ramírez, R., \& Barrera, J. (2003). Evaluación de cultivares de ajo morado y blanco por su rendimiento agronómico e industrial en Irapuato, Guanajuato. Acta Universitaria. 13(3), 57-65. Instituto de Ciencias Agrícolas. Universidad de Guanajuato. México.
Quemada, M., Delgado, A., Mateos, L., \& Villalobos, F. J. (2017). La fertilización nitrogenada II: Las necesidades de fertilizantes. In F. Villalobos, \& E. Fereres (Eds.), Fitotecnia Principios de agronomía para una agricultura sostenible (pp. 411-423). Madrid, España: Mundi-Prensa.

Salomon, R. (2002) Virus diseases in garlic and the propagation of virus-free plants. En H.D. Rabinowitch, \& L. Currah (Eds.), Allium Crop Science: Recent Advances (pp. 311-327). Wallingford, Reino Unido: CAB International.

Sierra, A., Simonne, E., \& Treadwell, D. (2007). Principios y prácticas para el manejo de nutrientes en la producción de hortalizas. Florida, EE.UU.: University of Florida.

Sifuentes, E., Albújar, V., \& Cajas, J. (2017). Producción Agrícola. En Boletín estadístico de producción agrícola y ganadera. II trimestre 2017. Ministerio de Agricultura y Riego. Retrieved from http://siea. minagri.gob.pe/siea/sites/default/files/produccionagricola-ganadera-iitrimestre2017_041017.pdf

Sifuentes, E., Albújar, V., \& Cajas, J. (2018). Producción Agrícola. En Boletín estadístico de producción agrícola y ganadera. IV trimestre 2017. Ministerio de Agricultura y Riego. Retrieved from http://siea. minagri.gob.pe/siea/sites/default/files/produccionagricola-ganadera-ivtrimestre2017_220318_0.pdf

Ugás, R., Siura, S., Delgado, F., Casas, A., \& Toledo, J. (2000). Hortalizas. Datos básicos. Lima, Perú: Programa de Investigación en Hortalizas, UNALM.

Usman, M., Fagam, A., Dayi, R., \& Isah, Z. (2016). Phenotypic response of two garlic varieties to different nitrogen fertilization grown under irrigation in Sudan Savannah ecological zone of Nigeria. International Journal of Agronomy, 2016, 1-10. http://dx.doi.org/10.1155/2016/2495828

Valladolid, A. (2001). El cultivo del frijol (Phaseolus vulgaris L.) en la costa del Perú. Lima, Perú. INIA. Retrieved from http://repositorio.inia.gob. pe/handle/inia/860 